\title{
SUSTAINABLE INNOVATION OF INDUSTRIAL COMPANIES
}

\author{
Iveta Simberova $^{1}$, Ales Krmela ${ }^{2}$, Peter Kita ${ }^{3}$ \\ 1, 2, ${ }^{3}$ Department of Management, Faculty of Business and Management, \\ Brno University of Technology, Kolejni 2906/4, Brno, Czech Republic \\ E-mails: ${ }^{1}$ simberova@fbm.vutbr.cz (corresponding author); ${ }^{2}$ ales.krmela@vut.cz; \\ ${ }^{3}$ kitap@fbm.vutbr.cz
}

\begin{abstract}
The objective of the paper is to dynamically capture the changes and trends in the innovation of business models of industrial enterprises, which owing to the incorporation of any other potential stakeholders in value creation, addresses the issue of limited resources for product innovation. The methodological objectives of the paper are based on the theory of systems approach and the Resource Base View (RBV). A primary literary source review on papers and studies published in peer-reviewed journals has been conducted. Our view, which has received increasing attention in the scientific literature, is associated with opportunities, but also barriers arising from the changes and trends in the environment as a challenge for sustainable innovation of the business model by means of finding a new space for innovation in areas where competition is not active. The main output show, that business models should be viewed from a dynamic perspective. The basis for this is the prospect of developing or innovating of the business model as a result of internal and external changes over time.
\end{abstract}

Keywords: business models, sustainable innovation, industrial companies, dynamics, value creation.

JEL Classification: M00, O31, Q56.

\section{Introduction}

The challenge for innovation in the context of the global trends is the need to seek solutions to new innovations comprehensively, while proceeding from system resource utilisation, integration and interconnection of various technologies and creative solutions across related industries. It means respecting the potential of vertical and horizontal integrated and network solutions and trends in these fields, thus opening up opportunities for industrial companies in the following industries to learn, develop, adapt and respond in a changing digital world so as to succeed in a competitive market environment. It is no longer sufficient to compete only by differentiating in the area of innovation of product quality or services while providing them, or economies of scale, but what seems ever more important is the shift of emphasis on innovation in areas where competition is not active.

Changes in the global environment, rising demands of the stakeholders, pressure of the competitors, obsolescence of technologies and products pushes the management and owners of industrial companies to search inter alia for new managerial and business approaches and models that would ensure their success on the domestic, international and global markets.
Companies are usually not flexible in adapting the existing business models. The pressure of more stakeholders and changes in the environment pose a great challenge for innovation and new approaches to satisfy customer needs.

Firms often face an ambidexterity problem, when introducing a new or significantly modified $\mathrm{BM}$. The ambidexterity is understood as the ability of simultaneously running both the existing $\mathrm{BM}$, while fully exploiting it, and a new BM that is about to be explored (e.g. Markides, 2013; Khanagha, Volberda, \& Oshri, 2014; Kranz, Hanelt, \& Kolbe, 2016). Ambidexterity is particularly relevant for established firms with wellproven BMs. The risk of not letting an emerging BM flourish is enormous, due to internal resistance, rigidity, or inability to change. Path dependence as an inhibitor of the BM change has been mentioned as well (Brunninge \& Wramsby, 2014).

Changes that can be expected in the orientation of business models are a reflection of the changes in the external environment. Companies need to adapt to these changes, and the challenges are precisely built-in relationships with stakeholders that open up the potential for innovation based on co-creating values of the offer. 
Our view, which has received increasing attention in the scientific literature, is associated with opportunities, but also barriers arising from changes and global trends as a challenge for sustainable innovation of the business model by means of finding a new space for innovation in areas where competition is not active. Hence, one result from our literature review consists in the fact that the business model of a company, whole industry or business philosophy is seen as a mediator for innovations that not only link production and consumption but also embrace stakeholders and their expectations from non-business areas. It has become clear that the business model perspective reveals a number of components that need to be actively managed in order to "create customer and social value by integrating social, environmental, and business activities." (Schaltegger, Lüdeke-Freund, \& Hansen, 2012b).

Activity system perspective - open business model By applying the perspective of conceptualization of the business model based on the system of independent activities exceeding the core focus of the company, we can monitor - in conformity with the stakeholders - the value creation and also suitable co-participation in this value.

The activity system (Zott \& Amit, 2010) seems to be a suitable instrument for analysing and innovating the existing business models with respect to the running and expected changes in the environment and incorporation of the stakeholders as the integral part of business model innovation.

The model defines the structure of the value chain (an activity based concept), creation of the multiple value by determining the set of activities, starting by the initial utilisation of opportunities and ending by the final customer, and the value added in the course of different activities, owing to which the company can rely on stakeholders' sources and possibilities and utilise external ideas and technologies through the "open business models".

Dynamic consistency The business model as above relates in general to comprehensible manifestation and understanding of mutually differing activity spheres of the company forming proposals of value creation for the customers. For its determination, it is necessary to consider not only the static form, but even the dynamics connected with changes of the basic business model. In the professional literature, the authors consider two approaches: static and transformation.

Demil and Lecocq (2010) describe the static approach as the plan for logical cohesion of the basic business model elements and the second transformation approach - rather as the instrument focused on changes and innovations in the company or in the model itself. The transformation approach enables to capture the innovations procedurally and to implement/perform them. The deductive approach at first identifies the basic elements in correspondence with the static approach and then establishes how these elements are changed at the organizational level.

The questions based on our knowledge relate to: a) finding factors which can influence sustainable innovations of BM industrial enterprises; $b$ ) the classification of BM parameters and sub-elements influencing the dynamics of these BMs.

The aim is to capture the changes and trends in the area of sustainable innovation of BM of industrial companies that, through the involvement of other potential stakeholders in value co-creation, address the issue of scarce resources for product innovation and creating the potential for sustainability of innovation.

\section{Business models and sustainable innovation}

The issue of approaches focused on determination of the business models is associated with changes in the environment indicating that the contemporary economic ideas are no more sustainable, new approaches in organizing include sustainability as the key essence which has to be considered and thought about, and the needs to search for answers to this development appear more and more intensively. Changing the link between the business and the company is one of further critical issues which seem to be absolutely clear. But it is not quite evident what roles, responsibilities and functions should be defined and resolved within the scope of this transformation.

Multiple customer value is a challenge and should be a strategic part of the business model. It could be solved by the organisational structure, processes and systems as a detailed part of strategic plan (Osterwalder \& Pigneur, 2010).

Sustainability offers vital business goals for the stakeholders (Epstein \& Roy, 2003; Hart, 2007; WBCSD, 2008; Worldwatch Institute, 2008; WEF, 2009; Nidumolu, Prahalad, \& Rangaswami, 2009; Pfeffer, 2010).

In this respect, many authors, theoreticians and practitioners emphasise the importance of the business based on development of sustainable consumption and production (Tukker \& Tischner, 2006; Tukker et al., 2008; Wells, 2008; Johnson, 2010; Sujith \& Paulose 2013). Tukker et al. 
(2008) and Sujith, Paulose (2013) for instance indicate that Osterwalder for the business models, the meta-factors and strategic innovations are understood the elements which could support accommodation and adaptation of cleaner products and processes, sustainable supply chains and other changes leading towards sustainability.

Wells (2008) and Sujith and Paulose (2013) stresses that alternative business models are the core ones for reaching sustainable consumption and production.

Tukker et al. (2008) notes that business is prepared best for positive reaction to sustainable challenges through radical innovations of products, services and related new business models.

A new approach proves repeatedly that for a comprehensive set of industries, the innovative new business models can create a solid base for future corporate success.

\subsection{Business models and corporate stakeholders' relationships management}

Creating beneficial and strong relationships requests real understanding of the potential and means of different stakeholders groups (incl. their wishes, needs and objectives).

Maximising the value creation by exploring and identifying new opportunities and advantages for the target customers in the areas determined by individual approaches represents a great benefit of these models (Simberova, 2010).

The new business models maximise the value by improving the relationships management with the customers, employees and other stakeholders groups in the so-called business networks and partnerships extending beyond national borders.

The scientists (Mitchell, Agle, \& Wood, 1997; Harrison \& Freeman, 1999; Winn \& Keller, 2001; Bryson, 2003; Payne, 2005; Kotler \& Keller, 2007; Raudeliūnienè, Davidavičienè, Tvaronavičienè, \& Jonuška, 2018) deal in their studies with individual aspects establishing these relationships.

Achtenhagen, Melin, and Naldi (2013) point out to the fact that the companies, with the capacity to create value from a long-term perspective, shape, adapt and renew their business models successfully and can support and increase this value creation.

Moreover, while creating and delivering customer value, the business model itself can become a source of competitive advantage - by means of the business model innovation (e.g., Mitchell \& Coles, 2003; Chesbrough, 2010; Johnson, 2010; Boons \& Lüdeke-Freund, 2013).
This confirms our idea that the business model concept may help to bring these elements into the research on sustainable innovation.

\subsection{Definition of the business model}

Business models have grown in significance in the last few years not only in practice but also in scientific research. Osterwalder, Pigneur, and Tucci (2005) notes that against this background, it is no wonder that business models are still relatively poorly understood, particularly as a research area. The many fundamental questions in the context of business model still remain unanswered (Wirtz, Pistoia, Ullrich, \& Göttel, 2016). Teece (2010) states that "the concept of business model lacks theoretical grounding in economics or in business studies". Wirtz et al. (2016) have analysed business models definitions and developed the definition of the business model based on the literature review and corresponds well with our research proposal. "A business model is a simplified and aggregated representation of the relevant activities of a company. It describes how marketable information, products and/or services are generated by means of a company's value-added component. In addition to the architecture of value creation, strategic as well as customer and market components are taken into consideration, in order to achieve the superordinate goal of generating, or rather, securing the competitive advantage. To fulfil this latter purpose, a current business model should always be critically regarded from a dynamic perspective, thus within the consciousness that there may be the need for business model evolution or business model innovation, due to internal or external changes over time" (Wirtz, Schilke, \& Ullrich, 2010). Considering that the model is a simplification of reality with specific purpose, the construction of business models for sustainable innovation of enterprises can represent a simplification of the logic of enterprise use to engage their set of objectives, concepts and relationships to contribute to global sustainable development.

\subsection{Sustainability and company size}

Incorporating the sustainability and company size into the research framework of designing business models for sustainable innovation of industrial companies is one of the important issue to which attention should be paid. The recent research (Hörisch, Johnson, \& Schaltegger, 2015) shows that sustainability management tools have been Schaltegger developed for both large and small companies. In their research, Hörisch et al. (2015) 
confirmed this thesis and but showed that knowledge, using and differences in the application of the sustainability management tools are different for both large and small companies. The sample of the research (328 enterprises) was predominantly industrial enterprises (171) and the research results well support our research purpose in the area of research sample object and object and subject of research.

Sustainable innovation Recently, more researchers have considered sustainable innovation to be the future source of business innovation turning sustainable challenges into revised products, services, processes or new business models (Holmes \& Moir, 2007; Gallego-Alvarez, PradoLorenzo, \& Garcia-Sanchez, 2011; Jamali, Yianni, \& Abdallah, 2011; Aagaard, 2012; Boons \& Lüdeke-Freund, 2013; Aagaard \& Lindgren, 2015).

Sustainable innovation is defined in terms of a new business trend, where businesses realize that social and environmental issues may be commercially profitable (Warhurst, 2005; Austin \& Seitanidi, 2011; Aagaard, 2012; Aagaard \& Lindgren, 2015). Additionally, Boons and LüdekeFreund (2013), Davidavičienè, Pabedinskaitè, and Davidavičius (2017), Kendiukhov andTvaronavičienè (2017) have noted the importance of intercompanies relations with stakeholders.

The sustainable innovation approach is based on wider approaches of sustainable development and environmental sustainability (e.g. Boons, 2009; Boons and Lüdeke-Freund, 2013; CarrilloHermosilla, del Río, \& Könnölä, 2010). Comparable conceptual notions of sustainable business models do not exist today (Boons and LüdekeFreund, 2013; Lüdeke-Freund, 2009; Schaltegger, Windolph, \& Herzig, 2012a). Current literature on sustainable innovation indicates that this process involves inter-companies relations or ecosystems. These are networks involving companies and their stakeholders.

\subsection{Dynamism of business models and sustainable innovation}

Business models and their dynamism (Life Cycle) Significant progress has been made from the initial interest in business models of the towards the development of concepts of these business models. The latest progress in development of these approaches monitors insight into the essence and understanding of business models dynamism, how these new business models respond to the needs of an enterprise during their life cycle with the objective to create a permanent value (Achtenhagen et al., 2013). The enterprises, successful for a certain time period and considering the risk of stereotype-based failure, stress that adapting their business model to the changes in the competitive environment is of great importance (Doz \& Kosonen, 2010). Permanent value creation relies on the successful adaptation and restoration of the basic corporate business model on the continuous basis which contains substantiation of how the organization creates, supplies and captures value (Osterwalder and Pigneur, 2010). The issues of monitoring of the so-called "black box" activities of the business model receive a great attention in the research and studies (Zott \& Amit, 2010). Achtenhagen et al. (2013) point out to the fact that the companies, with the capacity to create value from a long-term perspective, shape, adapt and renew their business models successfully and can support and increase this value creation. In association with the analysis of research of the permanently expanding companies, the authors show three critical capabilities and skills, namely focus on experimentation with utilisation of new business opportunities, balanced utilisation of resources, as well as reach of harmony between management, culture and employee commitment which together form the key strategic actions (Demil \& Lecocq, 2010; McGrath, 2010; Teece, 2010). By applying suitable business models, it is possible to analyse the market and bring innovations (incl. a new product, a new enterprise and supporting networks).

Our knowledge-based literature study shows that the company's business model is seen as a source of innovation bringing together production and consumption but also stakeholders and their desires and expectations (Boons \& LüdekeFreund, 2013). It has become clear that the business model perspective reveals a number of components that need to be actively managed in order to "create customer and social value by integrating social, environmental, and business activities." (Schaltegger et al., 2012b).

The activity-based concept of the business model characterises the structure of the value chain, creation of the multiple value by determining the set of activities, starting by the initial utilisation of opportunities and ending by the final customer, and the value added in the course of different activities, owing to which the company can rely on stakeholders' sources and possibilities and create new ideas through the "open business models. 
The BM as above relates in general to comprehensible manifestation and understanding of mutually differing activity spheres of the company forming proposals of value creation for the customers. For its determination, it is necessary to consider not only the static form, but even the dynamics associated with changes of the basic business model.

In the professional literature, authors consider two approaches: static and transformation. Demil and Lecocq (2010) describe the static approach as the plan for logical cohesion of the basic business model elements and the second transformation approach - rather as the instrument focused on changes and innovations in the company or in the model itself.

The transformation approach enables to capture the innovations procedurally and to implement/perform them. The deductive approach at first identifies the basic elements in correspondence with the static approach and then establishes how these elements are changed at the organizational level.

\subsection{Classification of $B M$ parameters and partial BM elements}

The question is what the parameters of the $\mathrm{BM}$ are and what the component BM elements are?

However, a number of researchers have so far focused on the BM from the static perspective. They study the business model topic particularly from its ontological perspective - aiming to define the term itself, to establish a normative basis on what a typical BM looks like, what the typical BM parameters and elements are. Osterwalder and Pigneur (2010) have identified nine so-called building blocks of a typical BM, i.e. the key partners, key activities, key resources, value proposition, customer relationships, customer segments, delivery channels, cost structure, and revenue streams. These are specific dimensions of the otherwise abstract BM construction.

Casadesus-Masanell and Ricart (2010) describe the BM as a reflection of the firm's realized strategy. They see the BM as an object, being characterised by its content, structure and governance.

At first, we identify the basic elements in correspondence with the static approach and then establish how these elements are changed at the organizational level. Demil and Lecocq (2010) speak about "dynamic consistency". In their opinion, BM dynamics stems from interactions between and inside the key BM components. We suppose that the dynamism of the BM should be explored by two parameters: internal and external.

The BM is impacted and changes both through external and internal factors. Internal factors are particularly company management's specific decisions, as well as results from dynamics between the single BM components or inside them. External factors generally include the business ecosystem, i.e. stakeholders, namely new competitors, substitutes or an impact through resources.

Typically, in dynamic business models, the parameters and elements reinforce each other.

\section{Methods and materials}

The methodological objectives of the paper are based on the theory of systems approach and the Resource Base View (RBV). A primary literary source review on papers and studies published in peer-reviewed journals has been conducted. The intend research project aims at proposing a methodology for sustainable innovations, designing and monitoring the prototype of suitable business models of industrial companies, defining the framework for forecasting the dynamics in relation to the consequences of global trends and the impact on performance.

For instance, Osterwalder and Pigneur (2010) recommends linking the BM with the SWOT analysis for the purposes of identifying the opportunities and threats which way determine the direction of the BM innovation. Lüttgens and Diener (2016) adopted Porter's five forces in order to analyse different threats to a business model. Pisano, Pironti, and Rieple (2015) applied the BIC methodology for analysing three important factors (Business Model, Innovation and Customer) and identification of combination of innovative trends (social, technological, psychological and economic).

Within the company performance measurement system, we will proceed from the latest approaches where the division of the approach and performance is supported with the help of financial and non-financial indicators consistently required by many authors (Bell \& Morse, 2008; Cokins, 2009; Kocmanová, Pavláková Dočekalová, \& Simanavičienè, 2017). Through a systematic analysis of available resources and literature, we will examine different approaches concerning the innovation of business models, specifying the key approaches and elements of business models for sustainable innovations. 


\section{Discussion}

One of the key attributes of a successful and sustainable BM is its difficult replicability through the existing or potential competitors (Teece, 2017). Every single BM can and probably will be, sooner or later, imitated, as long as it creates a sustainable economic value. Aiming to hinder the competitors in copying and thus sustaining the value created and captured, it is important that the company should possess one or several unique tangible or intangible assets, inherent in its BM. Typical examples include tacit knowledge, explicit specific skills, patents, exclusive agreements, and access to scarce resources. A successful BM is a system of components or so-called building blocks. Typically, in dynamic business models, the elements reinforce each other.

As long as one or more components are modified or removed, the BM is not the same any longer.

Accordingly, aiming to copy just some attributes of a BM, without having created a well harmonized, balanced, and functional system, where single components are in synergy and reinforce each other, are unlikely to be successful.

The current trends indicate that in order that a firm can survive in a fierce competition and a rapidly changing environment, innovation performance is one of its key capabilities.

A typical innovation in a firm or in an industry can be either product, process or business model related, or possibly a combination of two or even all three. The BM innovation (hereinafter only as the "BMI") has emerged lately as the promising option of the firm's innovation activities.

The IBM study (IBM, 2006) has originated that a significant number of top managers across various industries see the BMI as an increasingly powerful tool, therefore becoming undoubtedly their focus of interest. Particularly, companies that do suffer from a lack of resources required for a product or process innovation, can leverage on business model innovation instead.

However, a number of researchers have so far focused on the BM from the static perspective. They study the business model topic particularly from its ontological perspective - aiming to define the term itself, to establish a normative basis on what a typical BM looks like, what the typical BM components are. Osterwalder and Pigneur (2010) have identified nine so-called building blocks of a typical BM, i.e. the key partners, key activities, key resources, value proposition, customer relationships, customer segments, delivery channels, cost structure, and revenue streams. These are specific dimensions of the otherwise abstract BM construction.

The open business model is a result of definition the structure of the value chain (an activitybased concept), creation of the multiple value by determining the set of activities, starting by the initial utilisation of opportunities and ending by the final customer, and the value added in the course of different activities, owing to which the company can rely on stakeholders' sources and possibilities and utilise external ideas and technologies.

\section{Conclusions}

The industrial sector in Europe is a significant contributor to creating the Gross Domestic Product (GDP). By this way, it influences the level of the economy as a whole. Similarly, its impact is important in the sphere of satisfying human needs, thus affecting the standard of living. It plays a key role from the viewpoint of sustainable development.

The importance of reassessment and innovation of the past models is the key decision. It is no more enough to compete only by differentiating in the field of innovation of the quality of products, granted services or economies of scale, but switching the focus onto the innovations in the sectors free from the active competition seems, in much broader circumstances, to be more and more important. Changes in the global environment, rising demands of the stakeholders, pressure of the competitors, obsolescence of technologies and products pushes the management and owners of industrial companies to search inter alia for new managerial and business approaches and models that would ensure their success on the domestic, international and global markets.

Creating beneficial and strong relationships requests real understanding of the potential and means of different stakeholders groups (incl. their wishes, needs and objectives). Maximising the value creation by exploring and identifying new opportunities and advantages for the target customers in the areas determined by individual approaches is a great benefit of these models (Simberova, 2010). The new business models maximise the value by improving the relationships management with the customers, employees and other stakeholders groups in the so called business networks and partnerships extending beyond national borders (Simberova, 2010).

To achieve this goal, business models should be viewed from a dynamic perspective. The basis 
for this is the prospect of developing or innovating of the business model as a result of internal and external changes over time. The recent research (Schaltegger et al., 2012a; Hörisch et al., 2015) indicates that sustainability management tools have been developed for both large and small companies. In their research, Hörisch et al. (2015) confirmed this thesis and but showed that knowledge, using and differences in the application of the sustainability management tools are different for both large and small companies.

Sustainable innovation is defined in terms of a new business trend, where businesses realize that social and environmental issues may be commercially profitable (Aagaard \& Lindgren, 2015).

Our knowledge-based literature study shows that the company's business model is seen as a source of innovation bringing together production and consumption but also stakeholders and its desires and expectations (Boons \& Lüdeke-Freund, 2013). It is clear that the business model is composed from individual components. These components must be driven to create value for the customer, by integrating with social, environmental and economic activities.

\section{Acknowledgements}

The paper was supported by the research project entitled "Use of the Holistic Concept in Company Management" [grant number FP-J-18-4915].

\section{Disclosure statement}

The authors have no competing financial, professional or personal interests from other parties involved or interested in this research.

\section{References}

Aagaard, A. (2012). CSR with success - from theory to practice. Copenhagen Gyldendal Business.

Aagaard, A., \& Lindgren, P. (2015). The opportunities and challenges of persuasive technology in creating sustainable innovation and business model innovation. Wireless Personal Communications, 81(4), 1511-1529. https://doi.org/10.1007/s11277-015-2484-1

Achtenhagen, L., Melin, L., \& Naldi, L. (2013). Dynamics of business models - strategizing critical capabilities and activities for sustained value creation. Long Range Planning, 46(6), 427-442. https://doi.org/10.1016/j.lrp.2013.04.002

Austin, J. E., \& Seitanidi, M. (2011). Value creation in business - nonprofit collaborations. Working paper, 32, 194.

Bell, S., \& Morse, S. (2008). Sustainability indicators: Measuring the immeasurable. New York: Earthscan.
Boons, F. A. A. (2009). Creating ecological value. An evolutionary approach to business strategies and the natural environment. Elgar: Cheltenham. https://doi.org/10.4337/9781849801881

Boons, F., \& Lüdeke-Freund, F. (2013). Business models for sustainable innovation: state of the art and steps towards a research agenda. Journal of Cleaner Production, 45, 9-19. https://doi.org/10.1016/j.jclepro.2012.07.007

Brunninge, O., \& Wramsby, G. (2014). Avoiding to get stuck in a successful business model: dynamic business model adaptation from a path dependence perspective. The 3rd International Conference on Path Dependence (pp. 1-18). Berlin, Freie Universität Berlin School of Business \& Economics.

Bryson, J. M. (2003, February). What to do when stakeholders matter: A guide to stakeholder identification and analysis techniques. The paper presented at the London School of Economics and Political Science. Retrieved from $\mathrm{http} / /$ cep.lse.ac.uk/seminarpapers/10-02-03-BRY.pdf

Carrillo-Hermosilla, J., del Río, P., \& Könnölä, T. (2010). Diversity of eco-innovations: reflections from selected case studies. Journal of Cleaner Production, 18, 10731083. https://doi.org/10.1016/j.jclepro.2010.02.014

Casadesus-Masanell, R., \& Ricart, J. E. (2010). From strategy to business models and into tactics. Long Range Planning, 43(2), 195-215. https://doi.org/10.1016/j.lrp.2010.01.004

Cokins, G. (2009). Performance management: integrating strategy execution, methodologies, risk and analytics. New Jersey: John Wiley \& Sons.

Chesbrough, H. W. (2010). Business model innovation: opportunities and barriers. Long Range Planning, 43, 354-363. https://doi.org/10.1016/j.lrp.2009.07.010

Davidavičienè, V., Pabedinskaite, A. O., \& Davidavičius, S. (2017). Social networks in B2B and B2C communication. Transformations in Business and Economics, 16(1), 69-84.

Demil, B., \& Lecocq, X. (2010). Business model evolution: in search of dynamic consistency. Long Range Planning, 43, 227-246. https://doi.org/10.1016/j.lrp.2010.02.004

Doz, Y., \& Kosonen, M. (2010). Embedding strategic ability: a leadership agenda for accelerating business model renewal. Long Range Planning, 43(2-3), 370-382. https://doi.org/10.1016/j.lrp.2009.07.006

Epstein, M. J., \& Roy, M. J. (2003). Improving sustainability performance: specifying, implementing and measuring key principles. Journal of General Management, 29(1), 15-31. https://doi.org/10.1177/030630700302900101

Gallego-Alvarez, I., Prado-Lorenzo, J. M., \& GarciaSanchez, I. (2011). Corporate social responsibility and innovation: a resource-based theory. Management Decision, 49(19), 1709-1727. https://doi.org/10.1108/00251741111183843

Harrison, J. S., \& Freeman, R. E. (1999). Stakeholders, social responsibility, and performance: empirical evidence and theoretical perspectives. Academy of Management Journal, 42(5), 479-485.

Hart, S. (2007). Capitalism at the crossroads: aligning business, earth and humanity ( $2^{\text {nd }}$ ed.). New Jersey: Pearson Education Publishing.

Holmes, S., \& Moir, L. (2007). Developing a conceptual framework to identify corporate innovations through engagement with non-profit stakeholders. Corporate Governance, 7(4), 414-422. https://doi.org/10.1108/14720700710820498 
Hörisch, J., Johnson, M. P., \& Schaltegger, S. (2015). Implementation of sustainability management and company size: a knowledge based view. Business Strategy and Environment, 24, 765-779.

https://doi.org/10.1002/bse. 1844

IBM. (2006). Expanding the innovation horizon: the global CEO study 2006. Somers, USA: IBM Global Business Services. Retrieved from http://www-935.ibm. com/services/us/gbs/bus/pdf/ceostudy.pdf

Jamali, D., Yianni, M., \& Abdallah, H. (2011). Strategic partnerships, social capital and innovation: accounting for social alliance innovation. Business Ethics: A European Review, 20(4), 375-391. https://doi.org/10.1111/j.1467-8608.2011.01621.x

Johnson, M. W. (2010). Seizing the white space. Business model innovation for growth and renewal. Boston, MA: Harvard Business School Press.

Kocmanová, A., Pavláková Dočekalová, M., \& Simanavičienè, Ž. (2017). Corporate sustainability measurement and assessment of Czech manufacturing companies using a composite indicator. Engineering Economics, 28(1), 88-100.

Kendiukhov, I., \&Tvaronavičienė, M. (2017). Managing innovations in sustainable economic growth. Marketing and management of innovations, 3, 33-42. https://doi.org/10.21272/mmi.2017.3-03

Khanagha, S., Volberda, H., \& Oshri, I. (2014). Business model renewal and ambidexterity: structural alteration and strategy formation process during transition to a $\mathrm{C}$ loud business model. R\&D Management, 44(3), 322340. https://doi.org/10.1111/radm.12070

Kotler, P., \& Keller, K. L. (2007). Marketing management (12 $2^{\text {th }}$ ed.). Prague: Grada Publishing.

Kranz, J. J., Hanelt, A., \& Kolbe, L. M. (2016). Understanding the influence of absorptive capacity and ambidexterity on the process of business model change - the case of on premise and cloud computing software. Information Systems Journal, 26(5), 477-517. https://doi.org/10.1111/isj.12102

Lüdeke-Freund, F. (2009). Business model concepts in corporate sustainability contexts. From rhetoric to a generic template for 'business models for sustainability'. Centre for Sustainability Management: Lüneburg.

Lüttgens, D., \& Diener, K. (2016). Business model patterns used as a toou for creating (new) innovative business models. Journal of Business Models, 4(3), 19-36.

Markides, C. (2013). Business model innovations: what can the ambidexterity literature teach us?. The Academy of Management Perspectives, 27(4), 313. https://doi.org/10.5465/amp.2012.0172

McGrath, R. G. (2010). Business models: a discovery driven approach. Long Range Planning 43(2-3), 247-261. https://doi.org/10.1016/j.lrp.2009.07.005

Mitchell, R. K., Agle, B. A., \& Wood, D. J. (1997). Toward a theory of stakeholders identification and salience: defining the principles of who and chat really counts. Academy of Management Review, 22(4), 853-886. https://doi.org/10.5465/amr.1997.9711022105

Mitchell, D., \& Coles, C. (2003). The ultimate competitive advantage of continuing business model innovation. Journal of Business Strategy, 24, 15-22. https://doi.org/10.1108/02756660310504924

Nidumolu, R., Prahalad, C. K., \& Rangaswami, M. R. (2009). Why sustainability is now the key driver of innovation. Harvard Business Review, 87(9), 56-64.

Osterwalder, A., Pigneur, Y., \& Tucci, C. L. (2005). Clarifying business models: origins, present and future of the concept. Communications of the Association for Information Systems, 15(May), 1-38.

Osterwalder, A., \& Pigneur, Y. (2010). Business model generation: a handbook for visionaries, game changers and challengers. New Jersey: John Wiley \& Sons.

Payne, A. (2005). Handbook of customer relationship management: achieving excellence through customer management. Oxford: Elsevier.

Pfeffer, J. (2010). Building sustainable organizations: the human factor. Academy of Management Perspectives, 24(1), 34-45.

Pisano, P., Pironti, M., \& Rieple, A. (2015). Identify innovative business models: can innovative business models enable players to react to ongoing or unpredictable trends?. Entrepreneurship Research Journal, 5(3), 181-199. https://doi.org/10.1515/erj-2014-0032

Raudeliūnienè, J., Davidavičienè, V., Tvaronavičienè, M., \& Jonuška, L. (2018). Evaluation of advertising campaigns on social media networks. Sustainability, 10(4), $1-14$.

Schaltegger, S., Windolph, S., \& Herzig, C. (2012a). Applying the known. A longitudinal analysis of the knowledge and application of sustainability management tools in large German companies. Society and Economy, 34(4), 549-579. https://doi.org/10.1556/SocEc.34.2012.4.2

Schaltegger, S., Lüdeke-Freund, F., \& Hansen, E. G. (2012b). Business cases for sustainability - the role of business model innovation for corporate sustainability. International Journal of Innovation and Sustainable Development, 6(2), 95-119. https://doi.org/10.1504/IJISD.2012.046944

Simberova, I. (2010). Synergy in marketing management challenge for innovation of industrial company offer. In: Economics and Management - ICEM 2010 (pp. 10). Latvia: RTU Publishing House.

Sujith, N., \& Paulose, H. (2013). Emergence of green business models: the case of algae biofuel for aviation. Energy Policy, 65, 175-184.

Teece, D. J. (2010). Business models, business strategy and innovation. Long Range Planning 43(2-3), 172-194. https://doi.org/10.1016/j.lrp.2009.07.003

Teece, D. J. (2017). Business models and dynamic capabilities. Long Range Planning, 1-10. https://doi.org/10.1016/j.lrp.2017.06.007

Tukker, A., \& Tischner, U. (2006). Product-services as a research field: past, present and future. Reflection from $a$ decade of research, Energy Policy, 14(17), 1552-1556. https://doi.org/10.1016/j.jclepro.2006.01.022

Tukker, A., Emmert, S., Charter, M., Vezzoli, C., Sto, E., Munch Andersen, M., \& Lahlou, S. (2008). Fostering change to sustainable consumption and production: an evidence based view. Energy Policy, 16(11), 12181225.

Warhurst, A. (2005). Future roles of business in society: the expanding boundaries of corporate responsibility and a compelling case for partnership. Futures, 37(2), 151168. https://doi.org/10.1016/j.futures.2004.03.033

WBCSD. (2008). Sustainable consumption facts and trend from a business perspective. Geneva: World Business Council for Sustainable Development.

WEF. (2009). Sustainability for tomorrow's consumer: the business case for sustainability. Geneva: World Economic Forum.

Wells, P. (2008). Alternative business models for a sustainable automotive industry. Perspectives on Radical 
Changes to Sustainable Consumption and Production, 1(94), 80-98.

Winn, M. I., \& Keller, L. R. (2001). A modelling methodology for multi-objective multi-stakeholder decisions: Implications for research. Journal of Management Inquiry, 10(2), 166-181. https://doi.org/10.1177/1056492601102020

Wirtz, B. W., Schilke, O., \& Ullrich, S. (2010). Strategic development of business models. Long Range Planning, 43(2-3), 272-290.

https://doi.org/10.1016/j.lrp.2010.01.005
Wirtz, B. W., Pistoia, A., Ullrich, S., \& Göttel, V. (2016). Business models. Origin, development and future research perspectives. Long Range Planning, 46(1), 3654. https://doi.org/10.1016/j.lrp.2015.04.001

Worldwatch Institute. (2008). State of the world: Innovations for a sustainable economy. New York: W. W. Norton.

Zott, C. H., \& Amit, R. (2010). Business models design: an activity system perspective. Long Range Planning, 43(2-3), 216-226.

https://doi.org/10.1016/j.lrp.2009.07.004 